\title{
An Asymmetric Synthesis of Hamigeran B via a Pd AAA for Enantiodiscrimination
}

\author{
Barry M. Trost*, Carole Pissot-Soldermann, Irwin Chen and Gretchen M. Schroeder \\ Department of Chemistry, Stanford Univeristy, Stanford. CA. 94305-5080
}

General Experimental Conditions. All reactions were performed under an atmosphere of argon. Flasks were stored in a drying oven and cooled under argon prior to use. Solvents were distilled under an atmosphere of nitrogen before use. Tetrahydrofuran, 1,2-dimethoxy-ethane were distilled from sodium benzophenone ketyl. Diisopropylamine, pyridine, triethylamine were distilled over calcium hydride. All anhydrous solvents were transferred via oven-dried syringes or cannulae.

Analytical thin layer chromatography (TLC) was performed using $0.2 \mathrm{~mm}$ commercial silica gel plates (DC-Fertigplatten Kiselgel $60 \mathrm{~F}_{254}$ ). Flash chromatography was carried out with silica gel using the method of Still. Solvents for chromatography are described as percent by volume.

Melting points were measured on a Thomas-Hoover melting point apparatus in open capillaries and are uncorrected. Optical rotations were determined using a JASCO DIP-1000 polarimeter at the sodium D line $(589 \mathrm{~nm})$ using $50-\mathrm{mm}$ cells, with a concentration of $10.0 \mathrm{mg} / \mathrm{mL}$ expressed as $\mathrm{c}=1.00$. Chiral gas chromatography was performed on a Hewlett Packard 5890 Series II gas chromatograph. Infrared spectra were recorded on a Perkin Elmer Paragon 500 FT-IR spectrometer.

Proton nuclear magnetic resonance $\left({ }^{1} \mathrm{H}\right.$ NMR) spectra were recorded using a Varian Gemini 500 $(500 \mathrm{M} \mathrm{Hz})$ or Varian Gemini 300 (300 MHz) spectrometer. Chemical shifts are reported in delta

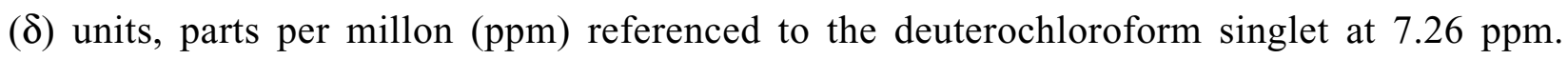
Coupling constants $(J)$ are reported in Hertz $(\mathrm{Hz})$. The following abbreviations for multiplicities are used: s, singlet; $d$, doublet; $t$, triplet; quin, quintet; dd, doublet of doublets; ddt, doublet of 
doublets of triplets; $\mathrm{m}$, multiplet. Carbon nuclear magnetic resonance $\left({ }^{13} \mathrm{C}\right.$ NMR $)$ spectra were recorded with broadband decoupling using a Varian Gemini $500(125 \mathrm{MHz})$ spectrometer. Chemical shifts are reported in delta $(\delta)$ units, parts per millon (ppm) referenced to the center line of the deuterochloroform triplet at $77.0 \mathrm{ppm}$.

Elemental analyses were performed by M-H-W Laboratories, Phoenix, AZ. High resolution mass spectra (HRMS) were obtained on a Kratos MS9 from the Mass Spectrometry Resource, School of Pharmacy, University of California, San Francisco. The exact mass is reported for the molecular ion $\left(\mathrm{M}^{+}\right)$as $\mathrm{M} / \mathrm{e}$.

\section{(S)-2-Allyl-5-tert-butoxymethylene-2-methyl-cyclopentanone (ent-6)}

A $1 \mathrm{~L}$ round bottom flask was charged with $165 \mathrm{~mL}$ of 1,2-dimethoxyethane (DME) and diisopropylamine $(10.12 \mathrm{~g}, 14.18 \mathrm{~mL}, 100 \mathrm{mmol})$. The solution was cooled to $-78_{\mathrm{i}} \mathrm{C}$ and $\mathrm{n}$ butyllithium (1.6M in hexanes, $62.4 \mathrm{~mL}, 100 \mathrm{mmol})$ was added dropwise. The resultant clear solution was stirred at $-78_{i} \mathrm{C}$ for 15 minutes and a solution of cyclopentanone 4 (9.115 g, 50 mmol) in $35 \mathrm{~mL}$ of DME was added via canula. The resultant orange solution was stirred at $0_{i} \mathrm{C}$ for $15 \mathrm{~min}$, charged with anhydrous tert-butanol $(25.94 \mathrm{~g}, 32.83 \mathrm{~mL}, 350 \mathrm{mmol})$, followed by a solution of trimethyltin chloride $(9.96 \mathrm{~g}, 50 \mathrm{mmol})$ in $35 \mathrm{~mL}$ of DME. The resultant red orange solution was stirred at $0_{i} \mathrm{C}$ for $15 \mathrm{~min}$ and then re-cooled to $-78_{i} \mathrm{C}$. To this solution was added a heterogeneous mixture of allyl palladium chloride dimer $(219 \mathrm{mg}, 0.6 \mathrm{mmol}),(R, R)$ Trost standard ligand (863 mg, $1.25 \mathrm{mmol})$, and allyl acetate $5 \mathrm{a}(11.01 \mathrm{~g}, 11.89 \mathrm{~mL}, 110 \mathrm{mmol})$ in 35 $\mathrm{mL}$ of DME. The resultant red-orange heterogeneous mixture was stirred overnight at room temperature. The reaction mixture was diluted with water $(200 \mathrm{~mL})$ and the layers were separated. The aqueous layer was re-extracted twice with ether $(2 \times 140 \mathrm{~mL})$, and the combined 
organics were washed with water and saturated brine $(1 \times 200 \mathrm{~mL}$ each $)$ and dried over magnesium sulfate. Concentration in vacuo, drying of the crude oil under high vacuum $(0.3$ Torrs) for $1 \mathrm{~h} 30$ and purification of the residue on silica gel (15\% ether/petroleum ether) afforded $8.56 \mathrm{~g}$ of ent-6 as yellow oil $(77 \%) . \mathrm{R}_{\mathrm{f}}=0.40$ (20\% ethyl acetate/petroleum ether); determination of enantiomeric excess : chiral GC (cyclosil B, isotherm $120 ; C) t_{R}($ major $)=70.162$ min, $t_{R}($ minor $)=71.370 \mathrm{~min} ;[\alpha]_{D}=-75.2 i,(c 1.47,26.9 j C$, chloroform, 93\% ee $)$; IR (neat) 2977, $2868,1708,1631,1456,1371,1264,1206,1156,980,945 \mathrm{~cm}^{-1} ;{ }^{1} \mathrm{H} \mathrm{NMR}\left(\mathrm{CDCl}_{3}, 500 \mathrm{MHz}\right)$ $\delta 7.51(\mathrm{t}, J=2.3,1 \mathrm{H}), 5.76-5.68(\mathrm{~m}, 1 \mathrm{H}), 5.05-5.00(\mathrm{~m}, 2 \mathrm{H}), 2.49-2.38(\mathrm{~m}, 2 \mathrm{H}), 2.19-2.11(\mathrm{~m}$, 2H), $1.84(\mathrm{ddd}, J=12.8,7.1,8.2,1 \mathrm{H}), 1.58(\mathrm{ddd}, J=12.8,6.4,7.7,1 \mathrm{H}), 1.35(\mathrm{~s}, 9 \mathrm{H}), 1.0(\mathrm{~s}, 3 \mathrm{H})$;

${ }^{13} \mathrm{C} \mathrm{NMR}\left(\mathrm{CDCl}_{3}, 125 \mathrm{MHz}\right) \delta 210.8,149.0,134.6,117.6,115.2,79.7,49.4,41.2,32.5,28.2$, 22.0, 21.2. Anal. Calc d for $\mathrm{C}_{14} \mathrm{H}_{22} \mathrm{O}_{2}$ : C, 75.63; H 9.97. Found C 75.84, H 10.18.

\section{2-Allyl-5-isopropyl-2-methyl-cyclopentanone (3)}

To a suspension of $\mathrm{CuI}(15.235 \mathrm{~g}, 80 \mathrm{mmol})$ in $200 \mathrm{~mL}$ of diethyl ether cooled to $-20 ¡ \mathrm{C}$ was added dropwise $100 \mathrm{~mL}$ of methyllithium (1.6M in ether, $160 \mathrm{mmol})$. The resultant clear colorless solution was stirred at $-20 ¡ \mathrm{C}$ for 30 minutes before a solution of cyclopentanone ent-6 (7.114 g, $32 \mathrm{mmol}$ ) in $30 \mathrm{~mL}$ of diethyl ether was added via cannula. The resultant clear orange solution was allowed to slowly warm to room temperature and stirred for $40 \mathrm{hrs}$. The resultant dark, heterogeneous reaction mixture was then carefully poured into an ice-cold saturated ammonium chloride solution $(250 \mathrm{~mL})$. The layers were filtered through a celite pad and separated. The aqueous layer was re-extracted twice with ether $(2 \times 250 \mathrm{~mL})$. The combined organics were washed with saturated brine $(1 \times 250 \mathrm{~mL})$ and with saturated sodium bicarbonate $(1 \times 250 \mathrm{~mL})$ and dried over magnesium sulfate. Concentration in vacuo and purification of the 
resultant crude liquid on silica gel (10\% ether/petroleum ether) afforded $5.135 \mathrm{~g}(89 \%)$ of a $(1: 1)$ diastereomeric mixture of $\mathbf{3}$ as a colorless liquid.

\section{(S)-trifluoro-methanesulfonic acid 5-allyl-2-isopropyl-5-methyl-cyclopent-1-enyl ester (7)}

To a solution of LDA [ prepared from diisopropylamine $(3.43 \mathrm{~g}, 4.8 \mathrm{~mL}, 33.9 \mathrm{mmol})$ and $\mathrm{n}$ butyllithium (1.6M in hexanes, $21 \mathrm{~mL}, 33.9 \mathrm{mmol})]$ in $130 \mathrm{~mL}$ of tetrahydrofuran (THF) cooled to $-78 \mathrm{i}$ C was added a solution of cyclopentanone $3(5.1 \mathrm{~g}, 28.2 \mathrm{mmol})$ in $25 \mathrm{~mL}$ of $\mathrm{THF}$. The resultant yellow solution was stirred at $0_{i} \mathrm{C}$ for 15 minutes before a solution of of $N, N$ phenylbistrifluoromethane-sulfonimide $(14.17 \mathrm{~g}, 39.67 \mathrm{mmol})$ in $40 \mathrm{~mL}$ of THF was added. The resultant orange solution was stirred at ambient temperature for three hours. The reaction mixture was poured onto a mixture of ether $(130 \mathrm{~mL})$ and water $(130 \mathrm{~mL})$ and the layers were separated. The aqueous layer was re-extracted twice more with ether $(2 \times 130 \mathrm{~mL})$. The combined organics were washed with water and saturated brine $(1 \times 200 \mathrm{~mL}$ each $)$ and dried over magnesium sulfate. Concentration in vacuo and purification of the resultant residue on silica gel (petroleum ether) afforded $7.685 \mathrm{~g}(87 \%)$ of vinyl triflate $7 . \mathrm{R}_{\mathrm{f}}=0.78(10 \%$ ether/petroleum ether $) ;[\alpha]_{\mathrm{D}}=$ $+6.9 \mathrm{i}(\mathrm{c} 1.2,27.0 \mathrm{i}$, chloroform, $93 \%$ ee $)$; chiral GC (cyclosil B, isotherm $120 ; \mathrm{C}) \mathrm{t}_{\mathrm{R}}($ major $)=$ $9.946 \mathrm{~min}, \mathrm{t}_{\mathrm{R}}($ minor $)=10.273$; IR (neat) $3080,2968,2875,1683,1642,1457,1409,1213,1142$, 1045, 1027, 877, 843, $610 \mathrm{~cm}^{-1} ;{ }^{1} \mathrm{H} \mathrm{NMR}\left(\mathrm{CDCl}_{3}, 500 \mathrm{MHz}\right) \delta 5.74(\mathrm{dddd}, J=18.3,10.2,8.1$, 6.6, 1H), 5.09-5.06 (m, 1H), 5.06-5.04 (m, 1H), 2.82 (hept., $J=6.8,1 \mathrm{H}), 2.28-2.17(\mathrm{~m}, 3 \mathrm{H}), 2.09$ (ddt, $J=13.8,8.1,1.0,1 \mathrm{H}), 1.94(\mathrm{ddd}, J=12.8,8.3,5.1,1 \mathrm{H}), 1.65(\mathrm{ddd}, J=12.8,8.9,6.2,1 \mathrm{H})$, $1.14(\mathrm{~s}, 3 \mathrm{H}), 1.02(\mathrm{~d}, J=6.8,3 \mathrm{H}), 1.00(\mathrm{~d}, J=6.8,3 \mathrm{H}) .{ }^{13} \mathrm{C} \mathrm{NMR}\left(\mathrm{CDCl}_{3}, 100 \mathrm{MHz}\right) \delta 144.9$, 138.0, 134.1, $118.6(J=317), 117.9,46.3,43.0,32.8,25.7,24.2,23.8,20.5,20.2$. HRMS Calc d for $\left(\mathrm{M}-\mathrm{C}_{3} \mathrm{H}_{5}\right)^{+} \mathrm{C}_{10} \mathrm{H}_{14} \mathrm{~F}_{3} \mathrm{O}_{3} \mathrm{~S}: 271.0616$. Found: 271.0618 . 


\section{1,3-dimethoxy-5-methyl-benzene (9)}

A mixture of orcinol $(3.1 \mathrm{~g}, 24.97 \mathrm{mmol})$ in $50 \mathrm{~mL}$ of dry acetone, dimethyl sulfate $(5.17 \mathrm{~mL}$, $6.89 \mathrm{~g}, 54.63 \mathrm{mmol})$ and potassium carbonate anhydrous $(7 \mathrm{~g}, 50.6 \mathrm{mmol})$ was heated under reflux under nitrogen for 24 hours. After cooling, the mixture was filtered, the residue was washed with acetone and the filtrate was evaporated in vacuo. The residue was then purified by distillation under reduced pressure to afford $3.5 \mathrm{~g}$ (92\%) of 1,3-dimethoxy-5-methyl-benzene 9 as a colorless liquid. $\mathrm{R}_{\mathrm{f}}=0.69$ (60\% ether / petroleum ether). B.p. $=60\left\lceil\mathrm{C}\right.$ under 0.25 torrs. ${ }^{1} \mathrm{H}$ NMR $\left(\mathrm{CDCl}_{3}, 300 \mathrm{MHz}\right) \delta 6.35-6.34(\mathrm{~m}, 2 \mathrm{H}), 6.30-6.29(\mathrm{~m}, 1 \mathrm{H}), 3.78(\mathrm{~s}, 6 \mathrm{H}), 2.32(\mathrm{~s}, 3 \mathrm{H})$.

\section{(S)-trifluoromethanesulfonic acid 2-isopropyl-5-methyl-5-(2-oxo-ethyl)-cyclopent-1-enyl ester (8)}

The vinyl triflate $7(1.898 \mathrm{~g}, 6.076 \mathrm{mmol})$ was taken up in $49 \mathrm{~mL}$ of tetrahydrofuran (THF) and $1.9 \mathrm{~mL}$ of water and cooled to $0_{i} \mathrm{C}$. To this solution was added $1.4 \mathrm{~mL}$ of an aqueous solution of osmium tetroxide ( $4 \mathrm{wt} \%$ in water, $0.23 \mathrm{mmol}, 3.77 \% \mathrm{~mol}$ ), followed by $1.2 \mathrm{~mL}$ of an aqueous solution of $\mathrm{N}$-methylmorpholine- $\mathrm{N}$-oxide (60 wt $\%$ in water, $6.94 \mathrm{mmol}$ ). The resultant orange mixture was stirred two hours at $0_{i} \mathrm{C}$ and overnight at room temperature. Sodium periodate (3.9 $\mathrm{g}, 18.23 \mathrm{mmol}$ ) was then added, together with $12 \mathrm{~mL}$ of water. The resultant white suspension was then stirred at room temperature for four hours. The reaction mixture was partitioned between ether and water. The aqueous layer was re-extracted twice more with ether, and the combined organics were washed once with saturated brine and dried over magnesium sulfate. Concentration in vacuo and filtration of the residue on silica gel (20\% ether/petroleum ether) afforded $1.809 \mathrm{~g}$ (94\%) of the aldehyde $\mathbf{8}$ as a light brown oil that darkened upon standing at room temperature. The aldehyde was unstable and was used immediately following isolation. 


\section{(S)-trifluoro-methanesulfonic acid 5-[2-(2,6-dimethoxy-4-methyl-phenyl)-2-oxo-ethyl]-2-}

\section{isopropyl-5-methyl-cyclopent-1-enyl ester (10)}

To a stirred solution of 1,3-dimethoxy-5-methyl-benzene 9 (2.093 g, $13.75 \mathrm{mmol})$ in $30 \mathrm{~mL}$ of 1,2-dimethoxyethane (DME) was added dropwise at $-78{ }_{i} \mathrm{C}$ a solution of n-butyllithium (1.55 M in hexanes, $13.75 \mathrm{mmol})$. The resultant clear solution was stirred for $30 \mathrm{~min}$ at $-78_{i} \mathrm{C}$ and 2 hours at room temperature. The white suspension was then recooled at $-78{ }_{i} \mathrm{C}$ and a solution of aldehyde 8 (3.579 g, $11.45 \mathrm{mmol})$ in $15 \mathrm{~mL}$ of DME was transferred via cannula. The resultant orange mixture was allowed to stir overnight at $-55_{i} \mathrm{C}$. The orange solution was then quenched with saturated ammonium chloride solution and extracted with ether. The aqueous layer was reextracted twice with ether. The combined ethereal extracts were washed with saturated brine, dried over magnesium sulfate and concentrated in vacuo. The crude residue was immediately set in the oxidation step. Crude mixture was dissolved in $200 \mathrm{~mL}$ of $\mathrm{CH}_{2} \mathrm{Cl}_{2}, \mathrm{NaHCO}_{3}(4.813 \mathrm{~g}, 57.3$ mmol) and Dess-Martin Periodinane ${ }^{2 ; 3}$ (7.776 g, 1.5 eq., $\left.1117.2 \mathrm{mmol}\right)$ were then added at room temperature. The resultant milky suspension was stirred for $1 \mathrm{~h}$. The reaction was then cooled to $0_{i} \mathrm{C}$ and quenched with a $1: 1$ mixture of $\mathrm{NaHCO}_{3}: \mathrm{Na}_{2} \mathrm{~S}_{2} \mathrm{O}_{3}$ solution. The reaction mixture was vigorously stirred until the organic layer become clear. The mixture was then poured into ether and washed with water and saturated brine. After drying over MgSO4 and evaporating, the crude mixture was purified by flash chromatography on silica gel (5\% to $\left.25 \% \mathrm{Et}_{2} \mathrm{O} / \mathrm{PE}\right)$ to afford $4.194 \mathrm{~g}$ of $\mathbf{1 0}$ as a white solid ( $75 \%$ over three steps from $\mathbf{7})$.

$\mathrm{R}_{\mathrm{f}}=0.35\left(30 \%\right.$ ether $/$ petroleum ether); m.p. $=62_{\mathrm{i}} \mathrm{C} ;[\alpha]_{\mathrm{D}}=21.8_{i}\left(\mathrm{c} 1.03,24.5_{i} \mathrm{C}\right.$, chloroform, $93 \%$ ee); IR (neat) 2967.3, 2360.6, 1711.9, 1609.0, 1582.9, 1464.1, 1408.5, 1212.7, 1139.0, 1045.9, 1029.4, 845.5 $\mathrm{cm}^{-1} ;{ }^{1} \mathrm{H}$ NMR $\left(\mathrm{CDCl}_{3}, 500 \mathrm{MHz}\right) \delta 6.34(\mathrm{~s}, 2 \mathrm{H}), 3.76(\mathrm{~s}, 6 \mathrm{H}), 3.01(\mathrm{~d}, J=$ $17.2,1 \mathrm{H}), 2.82(\mathrm{~d}, J=17.2,1 \mathrm{H}), 2.79$ (hept, $J=6.8,1 \mathrm{H}), 2.33(\mathrm{~s}, 3 \mathrm{H}), 2.33-2.30(\mathrm{~m}, 2 \mathrm{H}), 2.28-$ $2.22(\mathrm{~m}, 1 \mathrm{H}), 1.94(\mathrm{ddd}, J=12.8,6.5,6.3,1 \mathrm{H}), 1.27(\mathrm{~s}, 3 \mathrm{H}), 1.02(\mathrm{~d}, J=6.8,3 \mathrm{H}), 1.01(\mathrm{~d}, J=$ 
$6.8,3 \mathrm{H}) ;{ }^{13} \mathrm{C} \mathrm{NMR}\left(\mathrm{CDCl}_{3}, 125 \mathrm{MHz}\right) \delta 202.6,156.6,145.3,141.3,137.5,119.8,118.0(\mathrm{~J}=$ 320), 104.7, 51.1, 45.2, 33.5, 25.6, 23.9, 23.4, 22.2, 20.2, 20.1. Anal. Calc d for $\mathrm{C}_{21} \mathrm{H}_{27} \mathrm{~F}_{3} \mathrm{O}_{6} \mathrm{~S}: \mathrm{C}$, 54.30; H, 5.83; F, 12.27; S, 6.90. Found: C, 54.45; H, 5.83; F, 12.13; S 6.97.

\section{(S)-trifluoro-methanesulfonic acid 5-[2-(2-hydroxy-6-methoxy-4-methyl-phenyl)-2-oxo-} ethyl]-2-isopropyl-5-methyl-cyclopent-1-enyl ester (11)

To a solution of ketone 10 (446 mg, $0.96 \mathrm{mmol})$ in $15 \mathrm{~mL}$ of dichloromethane $\left(\mathrm{CH}_{2} \mathrm{Cl}_{2}\right)$, cooled to $-20_{i} \mathrm{C}$, was added dropwise a solution of boron trichloride ( $1 \mathrm{M}$ in hexanes, $\left.3 \mathrm{~mL}, 3 \mathrm{mmol}\right)$. The resultant red orange solution was stirred two hours and water $(30 \mathrm{~mL})$ was then added and the yellow mixture was stirred well for $5 \mathrm{~min}$. The layers were separated and the aqueous phase re-extracted with $\mathrm{CH}_{2} \mathrm{Cl}_{2}(3 \times 20 \mathrm{~mL})$. The pooled organic extracts were washed with a saturated sodium bicarbonate solution and dried over magnesium sulfate. Removal of solvents under reduced pressure and purification on silica gel (5\% to $30 \%$ ether / petroleum ether) afforded 333 mg of desired product $11(77 \%)$ as a white solid together with $46 \mathrm{mg}$ of unreacted starting material ( $86 \%$ based on recovered starting material). $\mathrm{R}_{\mathrm{f}}=0.60$ (30\% ether / petroleum ether); m.p. $=38-39_{i} \mathrm{C} ;[\alpha]_{\mathrm{D}}=-21.3 \mathrm{i}\left(\mathrm{c} 1.75,23.9_{i} \mathrm{C}\right.$, chloroform, $93 \%$ ee $)$; IR (neat) 2968.2, 2874.3, $2360.7,1629.1,1572.1,1458.2,1407.8,1284.9,1218.9,1140.4,1116.7,1029.5 \mathrm{~cm}^{-1} ;{ }^{1} \mathrm{H}$ NMR $\left(\mathrm{CDCl}_{3}, 500 \mathrm{MHz}\right) \delta 6.37(\mathrm{~m}, 1 \mathrm{H}), 6.18(\mathrm{~m}, 1 \mathrm{H}), 3.86(\mathrm{~s}, 3 \mathrm{H}), 3.40(\mathrm{~d}, J=17.3,1 \mathrm{H}), 3.15(\mathrm{~d}, J=$ 17.3, 1H), 2.81 (hept, $J=6.8,1 \mathrm{H}), 2.33-2.22(\mathrm{~m}, 2 \mathrm{H}), 2.29$ (s, 3H), 2.13 (ddd, $J=13.0,6.1,8.3$, $1 \mathrm{H}), 2.0(\mathrm{ddd}, J=13.4,5.0,8.6,1 \mathrm{H}), 1.28(\mathrm{~s}, 3 \mathrm{H}), 1.02(\mathrm{~d}, J=6.7,3 \mathrm{H}), 1.01(\mathrm{~d}, J=6.7,3 \mathrm{H}) ;{ }^{13} \mathrm{C}$ NMR $\left(\mathrm{CDCl}_{3}, 125 \mathrm{MHz}\right) \delta 204.5,164.6,161.0,147.5,145.5,137.8,118.6(J=318), 111.0$, 109.7, 102.4, 55.2, 50.9, 45.7, 33.6, 25.5, 23.9, 23.5, 22.2, 20.2. Anal. Calc d for $\mathrm{C}_{20} \mathrm{H}_{25} \mathrm{~F}_{3} \mathrm{O}_{6} \mathrm{~S}$ : C, 53.33; H, 5.59; F, 12.65; S, 7.12. Found: C 53.57, H 5.80 F 12.44; S 6.91. 


\section{(S)-1-(2-Hydroxy-6-methoxy-4-methyl-phenyl)-2-(3-isopropyl-1-methyl-cyclopent-2-enyl)-}

\section{ethanone (12)}

To a solution of triflate $11(318 \mathrm{mg}, 0.7 \mathrm{mmol})$ in $6 \mathrm{~mL}$ of $N, N$-dimethylformamide were successively added palladium (II) acetate (16 mg, $0.07 \mathrm{mmol})$, dppf (77 mg, $0.14 \mathrm{mmol})$, triethylamine $(283 \mathrm{mg}, 390 \mu \mathrm{l}, 2.8 \mathrm{mmol})$ and formic acid (161 mg, $132 \mu 1,3.5 \mathrm{mmol})$. The resultant orange solution was then heated at $70_{i} \mathrm{C}$ for one hour. The TLC showed a spot to spot reaction and the resultant suspension was then cooled to room temperature and partitioned between ether and water. The aqueous layer was re-extracted with ether $(3 \times 40 \mathrm{~mL})$ and the pooled ethereal extracts were washed with saturated ammonium chloride, saturated sodium bicarbonate and water $(1 \times 50 \mathrm{~mL}$ each $)$, dried over magnesium sulfate and concentrated in vacuo. The crude residue was filtered through a silica gel pad ( $5 \%$ ether, petroleum ether) to give $200 \mathrm{mg}(94 \%)$ of desired product 12 as a yellow oil. $\mathrm{R}_{\mathrm{f}}=0.55$ (20\% ether / petroleum ether); $[\alpha]_{\mathrm{D}}=20.4 \mathrm{i}$ (c 0.63, 22.2 iC, chloroform, $93 \%$ ee); IR (neat) 292959.1, 2867.5, 2360.3, 1626.9, 1574.0, 1455.9, 1410.7, 1365.7, 1283.9, 1220.7, 1115.1, 845.4, 814.3 $\mathrm{cm}^{-1} ;{ }^{1} \mathrm{H} \mathrm{NMR}\left(\mathrm{CDCl}_{3}, 500\right.$ MHz) $\delta 6.37(\mathrm{~m}, 1 \mathrm{H}), 6.16(\mathrm{~m}, 1 \mathrm{H}), 5.23(\mathrm{~m}, 1 \mathrm{H}), 3.85(\mathrm{~s}, 3 \mathrm{H}), 3.18(\mathrm{~d}, J=15.0,1 \mathrm{H}), 3.18(\mathrm{~d}, J=$ 15.0, 1H), $2.28(\mathrm{~s}, 3 \mathrm{H}), 2.27-2.16(\mathrm{~m}, 3 \mathrm{H}), 193(\mathrm{ddd}, J=12.8,8.5,5.8,1 \mathrm{H}), 1.72(\mathrm{ddd}, J=12.8$, 8.6, 5.8, 1H), $1.13(\mathrm{~s}, 3 \mathrm{H}), 0.95(\mathrm{~d}, J=6.8,3 \mathrm{H}), 0.92(\mathrm{~d}, J=6.8,3 \mathrm{H}) ;{ }^{13} \mathrm{C} \mathrm{NMR}\left(\mathrm{CDCl}_{3}, 125\right.$ MHz) $\delta 206.8,164.4,160.8,149.0,146.9,130.1,111.0,110.2,102.4,55.2,54.4,48.0,38.0,31.8$, $29.5,26.9,22.2,21.31,21.27$. 


\section{(S)-trifluoro-methanesulfonic acid 2-[2-(3-isopropyl-1-methyl-cyclopent-2-enyl)-acetyl]-3- methoxy-5-methyl-phenyl ester (2)}

To a solution of phenol $12(200 \mathrm{mg}, 0.66 \mathrm{mmol})$ in $3 \mathrm{~mL}$ of dichloromethane and $3 \mathrm{~mL}$ of pyridine was added dropwise at $0_{i} \mathrm{C}$ triflic anhydride $(222 \mu 1,373 \mathrm{mg}, 1.32 \mathrm{mmol})$. After one hour, the cooling bath was removed and the resultant orange solution was stirred at room temperature overnight. The reaction mixture was then partitioned between ether $(40 \mathrm{~mL})$ and water $(30 \mathrm{~mL})$. The aqueous layer was re-extracted twice with ether $(2 \times 40 \mathrm{~mL})$. The combined organics were washed once with $1 \mathrm{~N} \mathrm{HCl}$, twice with saturated copper (II) sulfate and once with saturated brine ( $50 \mathrm{~mL}$ each). After drying over magnesium sulafte and concentrating in vacuo, the resultant yellow oil was filtered through silica gel ( $25 \%$ ether / petroleum ether) to afford $268 \mathrm{mg}(94 \%)$ of desired aryl triflate $\mathbf{2}$ as a colorless oil. $\mathrm{R}_{\mathrm{f}}=0.39$ (30\% ether/petroleum ether);

$[\alpha]_{D}=20.3 i(c 1.15,22.3 i \mathrm{C}$, chloroform, $93 \%$ ee); IR (neat) 2960.6, 2360.4, 1699.2, 1618.9, $1574.3,1464.2,1425.7,1293.7,1217.5,1142.7,1071.1,976.5,837.8,816.3 \mathrm{~cm}^{-1} ;{ }^{1} \mathrm{H}$ NMR $\left(\mathrm{CDCl}_{3}, 500 \mathrm{MHz}\right) \delta 6.71(\mathrm{~s}, 2 \mathrm{H}), 5.20-5.19(\mathrm{~m}, 1 \mathrm{H}), 3.83(\mathrm{~s}, 3 \mathrm{H}), 2.90(\mathrm{~s}, 2 \mathrm{H}), 2.38(\mathrm{~s}, 3 \mathrm{H})$, 2.31-2.19 (m, 3H), $1.85(\mathrm{ddd}, J=12.8,8.4,5.2,1 \mathrm{H}), 1.72(\mathrm{ddd}, J=12.8,8.3,5.5,1 \mathrm{H}), 1.15(\mathrm{~s}$, $3 \mathrm{H}), 0.96(\mathrm{~d}, J=6.8,3 \mathrm{H}), 0.95(\mathrm{~d}, J=6.7,3 \mathrm{H}) ;{ }^{13} \mathrm{C} \mathrm{NMR}\left(\mathrm{CDCl}_{3}, 125 \mathrm{MHz}\right) \delta 200.2,157.3$, 149.3, 145.5, 142.3, 129.9, 122.8, $118.4(J=318 \mathrm{~Hz}), 114.0,111.7,56.1,55.2,47.1,37.7,31.8$, 29.5, 26.0, 21.8, 21.28, 21.24. Anal. Calc d for $\mathrm{C}_{20} \mathrm{H}_{25} \mathrm{~F}_{3} \mathrm{O}_{5} \mathrm{~S}: \mathrm{C}, 55.29 ; \mathrm{H}, 5.80 ; \mathrm{F}, 13.12 ; \mathrm{S}, 7.38$. Found: C, 55.51; H, 5.76; S 7.43. 


\section{(3aS,9bR)-1-Isopropyl-6-methoxy-3a,8-dimethyl-3,3a,4,9b-tetrahydro-}

\section{cyclopenta[a]naphthalen-5-one (13)}

The solvent used for the reaction is carefully degassed by sucessive freeze thaw cycles.

To a solution of $\mathrm{Pd}(\mathrm{OAc})_{2}(107 \mathrm{mg}, 0.48 \mathrm{mmol}, 10 \mathrm{~mol} \%)$ in $24 \mathrm{~mL}$ of toluene in a $100 \mathrm{~mL}$ round bottom flask, was added 1,3-(diphenylphosphino)butane (dppb) (409 mg, $0.96 \mathrm{mmol}, 20 \mathrm{~mol} \%$ ). After 15 min., a solution of triflate $2(2.084 \mathrm{mg}, 4.8 \mathrm{mmol})$ in $24 \mathrm{~mL}$ of toluene was added, followed by $\mathrm{K}_{2} \mathrm{CO}_{3}(1.904 \mathrm{~g}, 14.4 \mathrm{mmol}$, 3eq). After $5 \mathrm{~min}$., the reaction flask was fitted with a reflux condenser and heated at $107 \mathrm{i}$ for $8 \mathrm{~h}$ (oil bath already at desired temperature). The product distribution is then determinated by GC.After cooling the reaction mixture, the mixture is filtered through silica gel (5\% to $60 \%$ ether / petroleum ether ) to afford $1.2 \mathrm{~g}(91 \%)$ of Heck products containing $63 \%$ of the desired endocyclic double bond 13 .

$\mathrm{R}_{\mathrm{f}}=0.25(50 \%$ ether/petroleum ether $) ;[\alpha]_{\mathrm{D}}=170.0718( \pm 0.4607) \mathrm{i}(\mathrm{c} 0.39,26.5 \mathrm{i}$, chloroform, $93 \%$ ee); IR (neat) 2957, 2869, 1681, 1606, 1567, 1455, 1413, 1328, 1298, 1103, $1042 \mathrm{~cm}^{-1} ;{ }^{1} \mathrm{H}$ NMR $\left(\mathrm{CDCl}_{3}, 500 \mathrm{MHz}\right) \delta 6.69(\mathrm{~s}, 1 \mathrm{H}), 6.65(\mathrm{~s}, 1 \mathrm{H}), 5.40-5.39(\mathrm{~m}, 1 \mathrm{H}), 3.87(\mathrm{~s}, 3 \mathrm{H}), 3.56(\mathrm{~s}$, $1 \mathrm{H}), 2.80(\mathrm{~d}, J=14.5,1 \mathrm{H}), 2.37(\mathrm{~s}, 3 \mathrm{H}), 2.31(\mathrm{~d}, J=14.5,1 \mathrm{H}), 2.23-2.12(\mathrm{~m}, 3 \mathrm{H}), 1.22(\mathrm{~s}, 3 \mathrm{H})$, $1.11(\mathrm{~d}, J=6.7,3 \mathrm{H}), 0.77(\mathrm{~d}, J=6.7,3 \mathrm{H}) ;{ }^{13} \mathrm{C} \mathrm{NMR}\left(\mathrm{CDCl}_{3}, 125 \mathrm{MHz}\right) \delta 198.4,159.4,151.5$, $145.2,144.5,122.9,121.0,119.5,110.6,57.0,55.8,50.6,45.1,44.4,27.2,25.7,22.3,22.2,21.4$. HR-MS : Calc. for $\mathrm{C}_{19} \mathrm{H}_{24} \mathrm{O}_{2}(\mathrm{M})^{+}$: 284.1776. Found 284.1784

\section{(3aS,9bR)-6-Hydroxy-1-isopropyl-3a,8-dimethyl-3,3a,4,9b-tetrahydro- cyclopenta[a]naphthalen-5-one (13a)}


To a cooled solution $\left(-78{ }_{i} \mathrm{C}\right)$ of Heck products $(1.2 \mathrm{~g}, 4.22 \mathrm{mmol})$ in $140 \mathrm{~mL}$ of $\mathrm{CH}_{2} \mathrm{Cl}_{2}$, was added dropwise boron tribromide $(1.994 \mathrm{~mL}, 5.285 \mathrm{~g}, 21 \mathrm{mmol}$, 5eq). The resultant red solution was stirred at $-78_{i} \mathrm{C}$ for $45 \mathrm{~min}$. and then quenched with $80 \mathrm{~mL}$ of water. The reaction mixture was then partitioned between $\mathrm{Et}_{2} \mathrm{O}$ and $1 \mathrm{~N} \mathrm{HCl}$. The aqueous layer was re-extracted twice with $\mathrm{Et}_{2} \mathrm{O}$. The combined organics were washed with brine, dried over $\mathrm{MgSO}_{4}$ and concentrated in vacuo. The crude mixture was purified by flash chromatography on silica gel $\left(5 \% \mathrm{Et}_{2} \mathrm{O} /\right.$ petroleum ether) to afford $662 \mathrm{mg}$ ( $51 \%$ over 2 steps) of desired phenol 13a as colorless oil.

$\mathrm{R}_{\mathrm{f}}=0.60$ (50\% ether/petroleum ether); $[\alpha]_{\mathrm{D}}=136.2 \mathrm{i}(\mathrm{c} 1.43,24.7 \mathrm{i}$, dichloromethane); IR (neat) $3053,2959,2838,1634,1573,1453,1366,1307,1285,1257,1212,804 \mathrm{~cm}^{-1} ;{ }^{1} \mathrm{H}$ NMR $\left(\mathrm{CDCl}_{3}\right.$, $500 \mathrm{MHz}) \delta 12.5(\mathrm{~s}, 1 \mathrm{H}), 6.64(\mathrm{~s}, 1 \mathrm{H}), 6.60(\mathrm{~s}, 1 \mathrm{H}), 5.48(\mathrm{~m}, 1 \mathrm{H}), 3.55(\mathrm{~s}, 1 \mathrm{H}), 2.93(\mathrm{~d}, J=17$, $1 \mathrm{H}), 2.34(\mathrm{~s}, 3 \mathrm{H}), 2.29-2.23(\mathrm{~m}, 1 \mathrm{H}), 2.25(\mathrm{dd}, J=16.9,1.0,1 \mathrm{H}), 2.16$ (quint., $J=6.8,1 \mathrm{H}$ ), 2.08-2.04 (m, 1H), $1.22(\mathrm{~s}, 3 \mathrm{H}), 1.11(\mathrm{~d}, J=6.7,3 \mathrm{H}), 0.75(\mathrm{~d}, J=6.8,3 \mathrm{H}) ;{ }^{13} \mathrm{C}$ NMR $\left(\mathrm{CDCl}_{3}\right.$, $125 \mathrm{MHz}) \delta 204.7,162.8,151.4,147.8,143.2,122.2,120.9,116.0,113.8,56.3,47.0,45.9,45.1$, 27.3, 24.1, 22.4, 22.2, 22.0. HR-MS : Calc. for $\mathrm{C}_{18} \mathrm{H}_{22} \mathrm{O}_{2}(\mathrm{M})^{+}$: 270.1619; found 270.1624

\section{(3aS,9bR)-6-Hydroxy-1-isopropylidene-3a,8-dimethyl-1,2,3,3a,4,9b-hexahydro- cyclopenta[a]naphthalen-5-one (14a)}

$\mathrm{R}_{\mathrm{f}}=0.60(50 \%$ ether/petroleum ether $) ; \mathrm{mp}=106-107_{i} \mathrm{C} ;[\alpha]_{\mathrm{D}}=-331.5 \mathrm{i}\left(\mathrm{c} 0.52,27.4_{i} \mathrm{C}\right.$, dichloromethane); IR (neat) 2526, 1617, 1566, 1448, 1361, 1267, 1209, 1156, 1084, 1059, 849, $810,755 \mathrm{~cm}^{-1} ;{ }^{1} \mathrm{H}$ NMR $\left(\mathrm{CDCl}_{3}, 500 \mathrm{MHz}\right) \delta 12.7(\mathrm{~s}, 1 \mathrm{H}), 6.60(\mathrm{~s}, 1 \mathrm{H}), 6.50(\mathrm{~s}, 1 \mathrm{H}), 3.49(\mathrm{~s}$, $1 \mathrm{H}), 2.71(\mathrm{~d}, J=13.1,1 \mathrm{H}), 2.68(\mathrm{~d}, J=13.1,1 \mathrm{H}), 2.40-2.31(\mathrm{~m}, 1 \mathrm{H}), 2.28(\mathrm{~s}, 3 \mathrm{H}), 2.12-2.05(\mathrm{~m}$, 1H), $1.91(\mathrm{~s}, 3 \mathrm{H}), 1.72(\mathrm{~s}, 3 \mathrm{H}), 1.68-1.60(\mathrm{~m}, 1 \mathrm{H}), 1.46-1.39(\mathrm{~m}, 1 \mathrm{H}), 1.04(\mathrm{~s}, 3 \mathrm{H}) ;{ }^{13} \mathrm{C}$ NMR $\left(\mathrm{CDCl}_{3}, 125 \mathrm{MHz}\right) \delta 203.8,162.8,148.0,145.7,137.4,125.3,120.7,115.6,113.8,51.3,47.0$, 
41.8, 33.7, 27.5, 27.0, 22.5, 22.4, 20.6; Anal. Calc d for $\mathrm{C}_{18} \mathrm{H}_{22} \mathrm{O}_{2:} \mathrm{C}, 79.96$; H, 8.20. Found C, 79.68; H, 8.10.

\section{(1S,3aS,9bS)-6-Hydroxy-1-isopropyl-3a,8-dimethyl-1,2,3,3a,4,9b-hexahydro- cyclopenta[a]naphthalen-5-one (16)}

To a mixture of phenol (13a and 14a) $(55 \mathrm{mg}, 0.203 \mathrm{mmol})$ in $2 \mathrm{~mL}$ of ethanol was added palladium on activated carbon (10\% wt. on activated carbon, $25 \mathrm{mg})$. The resultant heterogeneous mixture was subjected to $1500 \mathrm{psi}$ of hydrogen for $20 \mathrm{~h}$, at room temperature. After filtration on a celite pad and evaporation of the solvents in vacuo, the crude residue was purified by flash chromatography on silica gel ( $20 \%$ ether / petroleum ether) to afford $35 \mathrm{mg}$ (62 $\%)$ of the product (16) as a white crystalline product. $\mathrm{R}_{\mathrm{f}}=0.56(20 \%$ ether / petroleum ether); m.p. $=93-96 i C ;[\alpha]_{D}=-56.1 ;(c 0.11,26.3 i C$, chloroform, 91\% ee); IR (neat) 2962, 2880, 2360, 1633.7, 1366, 1346, 1254, 802 $\mathrm{cm}^{-1} ;{ }^{1} \mathrm{H}$ NMR $\left(\mathrm{CDCl}_{3}, 500 \mathrm{MHz}\right) \delta 12.57(\mathrm{~s}, 1 \mathrm{H}), 6.61(\mathrm{~m}, 1 \mathrm{H})$, $6.40(\mathrm{~s}, 1 \mathrm{H}), 2.76(\mathrm{~d}, J=17.7,1 \mathrm{H}), 2.44(\mathrm{~d}, J=11.0,1 \mathrm{H}), 2.31(\mathrm{~s}, 3 \mathrm{H}), 2.27(\mathrm{dd}, J=17.7,1.3$, $1 \mathrm{H}), 2.02$ (dddd, $J=10.7,10.7,7.3,3.2,1 \mathrm{H}), 2.91$ (d quint., $J=6.8,3.2,1 \mathrm{H}), 1.78-1.69(\mathrm{~m}, 1 \mathrm{H})$, $1.68-1.60(\mathrm{~m}, 2 \mathrm{H}), 1.51-1.44(\mathrm{~m}, 1 \mathrm{H}), 1.06(\mathrm{~s}, 3 \mathrm{H}), 0.97(\mathrm{~d}, J=7.0,3 \mathrm{H}), 0.86(\mathrm{~d}, J=7.0,3 \mathrm{H})$;

${ }^{13} \mathrm{C}$ NMR $\left(\mathrm{CDCl}_{3}, 125 \mathrm{MHz}\right) \delta 204.4$ 163.1, 147.9, 146.1, 121.4, 115.8, 112.6, 52.0, 51.6, 45.7, $45.1,39.1,26.7,25.4,22.5,22.2,22.0,15.0$.

\section{(1R,3aS,9bS)-6-Hydroxy-1-isopropyl-3a,8-dimethyl-1,2,3,3a,4,9b-hexahydro- cyclopenta[a]naphthalen-5-one (17)}

To a solution of phenol 13a (562 mg, $2.078 \mathrm{mmol})$ in $21 \mathrm{~mL}$ of EtOH, was added Ir black from Aldrich (60 mg, $0.31 \mathrm{mmol}, 15 \mathrm{~mol} \%$ ). The heterogeneous solution was then charged with 1500 
psi of hydrogen pressure. The mixture was stirred at room temperature for $16 \mathrm{~h}$ and filtered over celite to leave $564 \mathrm{mg}$ of desired stereoisomer $\mathbf{1 7}$, as a white solid. $\mathrm{R}_{\mathrm{f}}=0.60(50 \%$ ether/petroleum ether); m.p $=142-143{ }_{i} \mathrm{C}($ EtOAc $/$ hexane $) ;[\alpha]_{D}=-59.9 i(\mathrm{c} 0.78,25.0 i \mathrm{C}$, chloroform, $93 \%$ ee); IR (neat) 2952, 2872, 2360, 1635, 1566, 1467, 1450, 1364, 1350, 1307, 1256, 1225, 1190, $804 \mathrm{~cm}^{-1} ;{ }^{1} \mathrm{H} \mathrm{NMR}\left(\mathrm{CDCl}_{3}, 500 \mathrm{MHz}\right) \delta 12.48(\mathrm{~s}, 1 \mathrm{H}), 6.60(\mathrm{~s}, 1 \mathrm{H}), 6.52(\mathrm{~s}$, 1H), $3.00(\mathrm{~d}, J=11.7,1 \mathrm{H}), 2.67(\mathrm{~d}, J=17.3,1 \mathrm{H}), 3.53-2.46(\mathrm{~m}, 1 \mathrm{H}), 2.32(\mathrm{~s}, 3 \mathrm{H}), 2.25(\mathrm{dd}, J=$ $17.3,1.4,1 \mathrm{H}), 1.86-1.81(\mathrm{~m}, 1 \mathrm{H}), 1.70-1.55(\mathrm{~m}, 4 \mathrm{H}), 1.10(\mathrm{~s}, 3 \mathrm{H}), 0.72(\mathrm{~d}, J=6.7,3 \mathrm{H}), 0.48(\mathrm{~d}$, $J=6.8,3 \mathrm{H}) ;{ }^{13} \mathrm{C} \mathrm{NMR}\left(\mathrm{CDCl}_{3}, 125 \mathrm{MHz}\right) \delta 205.2,162.3,147.5,144.7,123.2,115.5,114.6$, 51.8, 49.2, 46.0, 43.8, 39.6, 28.6, 26.9, 25.6, 23.5, 22.2, 18.2. Anal. Calc d for $\mathrm{C}_{18} \mathrm{H}_{24} \mathrm{O}_{2}: \mathrm{C}$, 79.37; H, 8.88. Found: C, 79.50; H, 8.83.

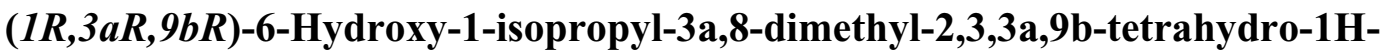

\section{cyclopenta[a]naphthalene-4,5-dione (18)}

To a solution of phenol $17 \mathrm{in} 7 \mathrm{ml}$ of dioxane, $225 \mu 1 \mathrm{H}_{2} \mathrm{O}$ and 1 drop of $\mathrm{AcOH}$, was added $\mathrm{SeO}_{2}$ (132 $\mathrm{mg}, 1.18 \mathrm{mmol}$ ). The resultant suspension was stirred for $24 \mathrm{~h}$ at $100 ; \mathrm{C}$. The yellow solution was then cooled down to room temperature and filtered through a silica gel pad to remove inorganic products. After evaporation, the crude mixture was purified by chromatography on silica gel ( $5 \%$ to $10 \% \mathrm{Et}_{2} \mathrm{O} / \mathrm{PE}$ ) to give $248 \mathrm{mg}$ of 18 as a yellow solid ( $73 \%$ yield) together with $60 \mathrm{mg}$ of starting material 17 (90\% BRSM).

$\mathrm{R}_{\mathrm{f}}=0.23(10 \%$ ether/petroleum ether $) ; \mathrm{m} . \mathrm{p}=92-93 ; \mathrm{C} ;[\alpha]_{\mathrm{D}}=-189.0_{i}(\mathrm{c} 0.29,23.7 ¡ \mathrm{C}$ dichloromethane); IR (neat) 2959, 1725, 1634, 1567, 1453, 1368, 1338, 1303, 1217, 1197, 1154, 1098, 1035, 936, 851, $743 \mathrm{~cm}^{-1} ;{ }^{1} \mathrm{H}$ NMR $\left(\mathrm{CDCl}_{3}, 500 \mathrm{MHz}\right) \delta 11.92(\mathrm{~s}, 1 \mathrm{H}), 6.72(\mathrm{~s}, 1 \mathrm{H}), 6.69$ (s, 1H), $3.39(\mathrm{~d}, J=9.1,1 \mathrm{H}), 2.61(\mathrm{ddd}, J=13.3,7.7,5.5,1 \mathrm{H}), 2.38(\mathrm{~s}, 3 \mathrm{H}), 2.30-2.24(\mathrm{~m}, 1 \mathrm{H})$, 
$1.83-1.76(\mathrm{~m}, 1 \mathrm{H}), 1.70-1.64(\mathrm{~m}, 1 \mathrm{H}), 1.57-1.51(\mathrm{~m}, 1 \mathrm{H}), 1.29(\mathrm{~s}, 3 \mathrm{H}), 1.24-1.16(\mathrm{~m}, 1 \mathrm{H}), 0.54$ $(\mathrm{d}, J=6.6,3 \mathrm{H}), 0.42(\mathrm{~d}, J=6.5,3 \mathrm{H}) ;{ }^{13} \mathrm{C} \mathrm{NMR}\left(\mathrm{CDCl}_{3}, 125 \mathrm{MHz}\right) \delta 200.1,184.3,164.6,150.8$, $144.1,123.4,116.7,116.2,56.8,56.4,51.4,33.8,28.1,26.9,24.4,23.2,22.5,19.8$. Anal. Calc d for $\mathrm{C}_{18} \mathrm{H}_{22} \mathrm{O}_{3}$ : C, 75.5; H, 7.74. Found C, 75.71; H, 7.49.

\section{Hamigeran B (1)}

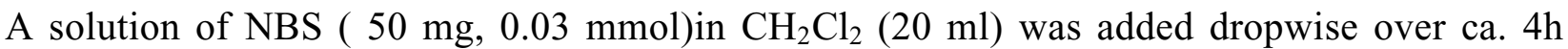
(syringue pump) to a stirred and cooled $\left(0_{i} \mathrm{C}\right)$ solution of diketone $18(80 \mathrm{mg}, 0.028 \mathrm{mmol})$ and $i$ - $\mathrm{Pr}_{2} \mathrm{NH}$ (ca. $\left.0.2 \mathrm{ml}, 0.14 \mathrm{mmol}\right)$ in $\mathrm{CH}_{2} \mathrm{Cl}_{2}(40 \mathrm{ml})$. The ice bath was removed and the mixture was stirred for 3h. Evaporation of the solvent and flash chromatography of the residue over silica gel, using $7: 3 \mathrm{CH}_{2} \mathrm{Cl}_{2}$ / toluene gave hamigeran $\mathrm{B}$ ( $86 \mathrm{mg}, 85 \%$ ) as a yellow solid.

$\mathrm{R}_{\mathrm{f}}=0.36\left(30 \%\right.$ toluene $\left./ \mathrm{CH}_{2} \mathrm{Cl}_{2}\right) ; \mathrm{m} . \mathrm{p}=162-163 ; \mathrm{C} ;[\alpha]_{\mathrm{D}}=-211.1 \mathrm{i}(\mathrm{c} 0.15,25.8 i \mathrm{C}$ dichloromethane); IR (neat) 2958, 2361, 1996, 1725, 1634, 1540, 1436, 1397, 1280, 1169, 1030, 778, $743 \mathrm{~cm}^{-1} ;{ }^{1} \mathrm{H} \mathrm{NMR}\left(\mathrm{CDCl}_{3}, 500 \mathrm{MHz}\right) \delta 12.6(\mathrm{~s}, 1 \mathrm{H}), 6.82(\mathrm{~s}, 1 \mathrm{H}), 3.39(\mathrm{~d}, J=9.2,1 \mathrm{H}), 2.64$ (ddd, $J=13.1,7.6,5.2,1 \mathrm{H}), 2.51(\mathrm{~s}, 3 \mathrm{H}), 2.34-2.27(\mathrm{~m}, 1 \mathrm{H}), 1.84-1.77(\mathrm{~m}, 1 \mathrm{H}), 1.72-1.65(\mathrm{~m}$, $1 \mathrm{H}), 1.58-1.52(\mathrm{~m}, 1 \mathrm{H}), 1.29(\mathrm{~s}, 3 \mathrm{H}), 1.22-1.16(\mathrm{~m}, 1 \mathrm{H}), 0.51(\mathrm{~d}, J=6.7,3 \mathrm{H}), 0.45(\mathrm{~d}, J=6.5$, $3 \mathrm{H}) ;{ }^{13} \mathrm{C} \mathrm{NMR}\left(\mathrm{CDCl}_{3}, 125 \mathrm{MHz}\right) \delta 199.0,184.4,160.8,150.2,142.7,124.2,117.2,111.5,56.9$, $56.2,51.2,33.7,28.1,26.7,24.4,24.3,23.3,19.7$.

\section{ORTEP for Structure 16}




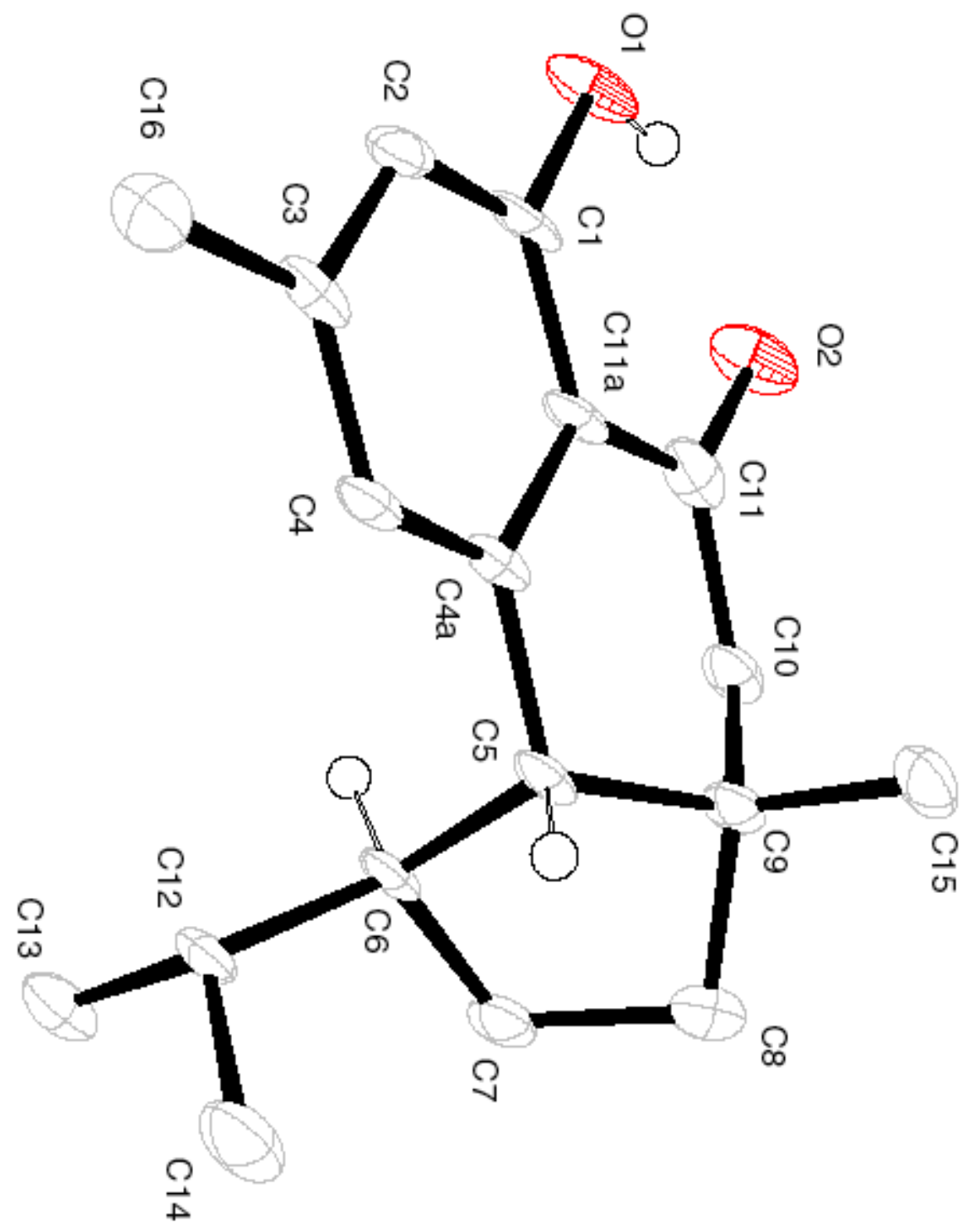




\section{ORTEP for Structure 17}

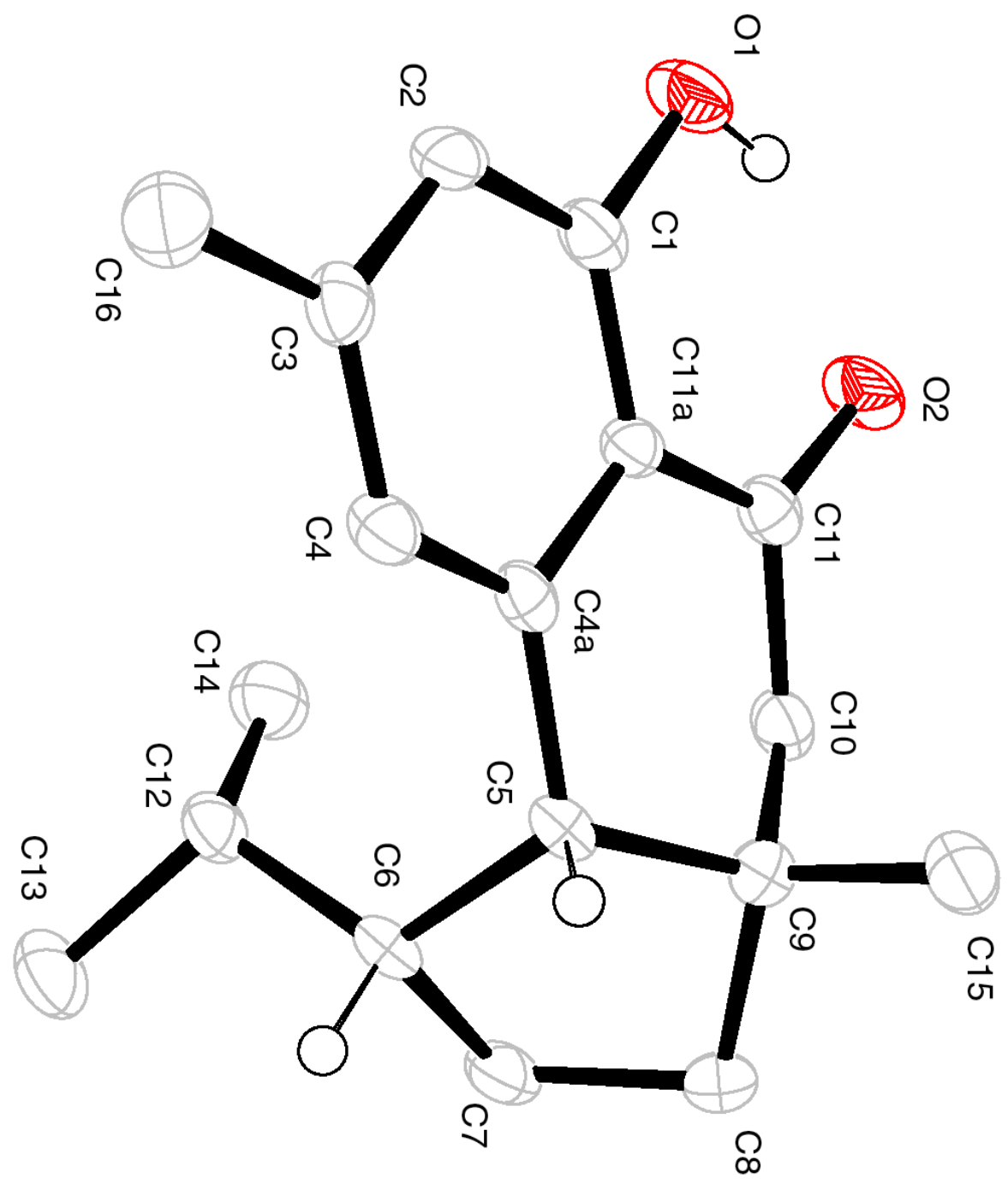




\section{Reference List}

(1) Schroeder, G. M. Palladium Catalyzed Asymmetric Allylic Alkylation (AAA) of Prochiral Nucleophiles: Efforts Toward the Syntheses of Erinacine A. 2002. Stanford University. Thesis/Dissertation

(2) Ireland, R. E.; Liu, L. J.Org.Chem. 1993, 58, 2899.

(3) Frigerio, M.; Santagostino, M.; Sputore, S. J.Org.Chem. 1999, 64, 4537. 